\title{
Estudo para desenvolvimento da Interface de um Aplicativo para Vegetarianos: estímulo aos novos adeptos
}

\section{Application Interface for Vegetarians: Encouragement new adepts}

GONÇALVES, Amanda Cristina; Graduada em Design Gráfico; Faculdade de Administração e Artes de Limeira - FAAL

amanda.goncalves2393@gmail.com

SNIKER, Tomas Guner; Doutor em Design e Arquitetura; Faculdade de Administração e Artes de Limeira - FAAL

tsniker@hotmail.com

\section{Resumo}

Este artigo apresenta os resultados de um estudo para o projeto de design de um aplicativo para vegetarianos, bem como para pessoas potencialmente interessadas em adentrar a este estilo de vida. O aplicativo foca-se em fornecer informações sobre receitas e ingredientes de modo prático e intuitivo para que os usuários preparem suas próprias refeições ao invés de somente frequentarem estabelecimentos que ofereçam a alimentação. Além disso, objetiva-se que o aplicativo concentre informações aos novos adeptos facilitando a adequação dos seus hábitos e possibilitando que este processo se torne uma experiência positiva.

Palavras-chave: Vegetarianismo; Aplicativo; Interface.

\begin{abstract}
This article presents the results of a study for the project of design of an application for vegetarians, as well as for people potentially interested in penetrating to this lifestyle. The application is focused in supplying information on recipes and ingredients in a practical and intuitive way so that the users prepare their own meals instead of they only frequent establishments to offer the feeding that you/they want. Besides, it is aimed at that the application concentrates information to their users facilitating the adaptation of their habits making possible that this process becomes a positive experience.
\end{abstract}

Keywords: Vegetarianism; App; Interface. 


\section{Introdução}

A predefinição mais comum entre as pessoas sobre o vegetarianismo consiste num estilo de alimentação voltado apenas para o consumo de saladas, porém o conceito vai muito além disso. O vegetarianismo não é uma nova forma de se alimentar, pelo contrário, possui anos de existência. Sugere-se que ainda na pré-história cerca de 5 milhões de anos atrás, os seres humanos não faziam uso da carne para sua alimentação, mas sim de frutas, folhas e sementes, estabelecendo a convivência harmoniosa com animais menores que poderiam ser facilmente capturados e consumidos (RODRIGUES, 2005).

Observa-se que o vegetarianismo vem atraindo cada vez mais adeptos, em decorrência disso, a busca por informações pelo tema torna-se cada vez maior. Deste modo, a procura por refeições e estabelecimentos que ofereçam opções neste segmento cresceu, assim como a busca por informações por meio de visitas aos nutricionistas ou por intermédio de sites, artigos e outros meios online.

A busca destes indivíduos por informações é essencial para que, ao adotar um novo padrão alimentar, não percam também o hábito de continuar preparando suas próprias refeições.

Nos últimos anos, observa-se também o avanço tecnológico da internet e outros meios eletrônicos, com isso a forma como a informação é adquirida e disseminada torna-se cada vez mais variada, a ubiquidade ${ }^{1}$ é uma nova realidade presente no cotidiano das pessoas, tornando comum nos dias de hoje que estas pessoas sintam a necessidade de estarem em mais de um local ao mesmo tempo.

Antes dos equipamentos móveis, nossa conexão as redes dependia de um interface fixa, os computadores de mesa. Enquanto as redes digitais, por sua própria natureza, são sempre móveis, a entrada nas redes implicava que o usuário estivesse parado à frente o ponto fixo do computador. Agora, ao carregar consigo um dispositivo móvel, a mobilidade se torna dupla: mobilidade informacional e mobilidade física do usuário. (SANTAELLA, 1983, p. 21)

Partindo desta observação, este trabalho visa o projeto de design de um aplicativo que forneça informações a um público em expansão: pessoas já vegetarianas e também para possíveis novos adeptos, que se preocupam em continuar preparando suas próprias refeições e buscam informações sobre receitas e ingredientes, ao invés de somente frequentarem estabelecimentos que ofereçam a alimentação que desejam. Além disso, a ideia central é que a interface do aplicativo possibilite aos seus usuários a imersão ao vegetarianismo de forma agradável e prática, possibilitando aos mesmos uma experiência positiva e satisfatória.

Segundo Bonsiepe (2011) a interface digital é um objeto de conexão para interação homem-computador e configura-se como um elemento funcional fundamental para que haja a aquisição da informação. Com esse propósito, a inclusão do design ação capaz de projetar e garantir um fluxo de interação ideal entre o artefato e o usuário final torna-se essencial nesse processo, pois este se apropria da retórica e reduz a complexidade da informação de modo a torná-la clara e favorecer sua compreensão sem reducionismos.

\footnotetext{
${ }^{1}$ Ubiquidade é a capacidade de um corpo estar em dois ou mais lugares ao mesmo tempo.
} 


\section{Método}

A propagação de aplicativos mobiles torna-se cada vez mais comum, para cada tema é possível encontrar diferentes possibilidades e funcionalidades. Amplia-se a oferta de novas alternativas, porém é somente por meio da busca do entendimento dos indivíduos e das necessidades que é possível projetar com assertividade.

Tendo em vista os objetivos propostos neste trabalho optou-se por adotar o método de projeto de Löbach (1976) como base fundamental para o processo de desenvolvimento. Segundo Löbach (1976), é possível traçar um roteiro que guie a elaboração de um projeto partindo-se apenas da identificação de uma necessidade ou apenas tendo em vista melhorar um produto já existente.

Somado ao método de Löbach (1976) utilizou-se também os princípios apresentados por Petterson (2012) relacionados ao design da informação no processo de organização de mensagens tendo vista tornar o acesso a informação eficaz e satisfatório. Ao todo são 16 princípios, divididos em quatro grupos: funcionais (A), administrativos (B), estéticos (C) e cognitivos (D):

(A) funcionais - são os princípios utilizados na fase inicial do projeto: Definir o problema etapa em que se analisa o emissor e receptor da informação, a mensagem pretendida e selecionase um meio e uma forma adequada para sua representação; Fornecer estrutura - deve-se desenvolver uma estrutura clara para o conteúdo, mostrando uma hierarquia por meio do design gráfico; Fornecer clareza visual - trata-se da legibilidade do material, sendo que o conteúdo deve se destacar claramente do fundo e a tipografia ter um bom tamanho. Proporcionar simplicidade a simplicidade de um material proporcionará ao receptor uma fácil percepção da mensagem. Fornecer ênfase - os elementos mais importantes do material de informação podem ser enfatizados para melhorar a atenção e a percepção. Fornecer unidade - materiais informativos devem ter unidade, ou seja, uma coerência e harmonia entre as partes.

(B) administrativos - são os princípios menos relacionados a parte gráfica em si e mais condizentes com a área administrativa do projeto: Acesso à informação - independentemente do meio escolhido e do sistema de distribuição, o receptor deverá ter fácil acesso às informações quando necessário; Custos - o designer deve ter controle sobre os custos para a concepção e produção do material informativo; Ética - deve-se respeitar o direito dos autores, bem como outras leis e regulamentos que estão relacionados com design, produção, distribuição, armazenamento e uso de informações; Garantir qualidade - trata-se da qualidade da informação. Dados e fatos devem estar corretos e precisam ser relevantes para a situação;

(C) estéticos - são os princípios que dizem respeito à estética: Harmonia- trata-se da relação entre os elementos gráficos presente no material, sendo que estes devem estar aptos a unirem-se de forma harmoniosa e equilibrada; Proporção estética: o designer deve descobrir as preferências estéticas do receptor, a fim de atender suas expectativas.

(D) cognitivos - são os princípios que dizem sobre a compreensão e o significado da mensagem transmitida: Facilitar a atenção - qualquer material informativo deve, constantemente, redesenhar a atenção a fim de manter o interesse do público; Facilitar a percepção: quando uma mensagem entra em contato com o receptor, são despertados novas emoções, experiências, sentimentos e conhecimentos; Facilitar o processamento mental: a informação deve ser simples, clara e sem possíveis ambiguidades; Memória: trata-se da retenção e armazenamento da 
informação.

Assim, Petterson (2012) destaca como objetivo principal do Design de Informação a clareza na comunicação, sendo que as apresentações visuais devem ser ainda esteticamente agradáveis e de fácil compreensão para quem a utiliza. Segue-se agora o processo de desenvolvimento tomando as 5 fases propostas por Lobach: (1) análise do problema; (2) definição do problema e dos objetos; (3) alternativas de design; (4) avaliação das alternativas de design; (5) solução de design.

De acordo com Löbach (1976) primeiramente deve-se analisar o problema, bem como o contexto no qual está inserido, levantando dados para serem instrumentalizados na elaboração de detalhes formais de um novo produto.

Tendo em vista a elaboração de um produto que facilite a vida humana, o trabalho de pesquisa para coleta e análise de dados permite que não ocorram erros graves, possibilitando a reunião de informações importantes de produtos similares encontrados em uso no mercado. A partir do trabalho de coleta e análise de dados se adquire uma visão abrangente sobre características indispensáveis ao entendimento dos usuários:

\section{A partir de experiências se resultam amostras, conclusões e informações, com isso, é possível levar a construção de modelos demonstrativos, podendo através destas experiências, destinar-se a resolução de problemas encontrados em seus produtos similares. (MUNARI, 1981)}

Considera-se que uma das melhores formas de se adquirir informações sobre um público especifico, é questionando a ele próprio sobre suas demandas. Deste modo, para execução deste trabalho, foi aplicado um questionário a um grupo destinado a adeptos do vegetarianismo na rede social Facebook. Contabilizando um total de 286 respostas em 7 dias de pesquisa online, no mês de Outubro de 2017. Acredita-se que a coleta de dados efetuada salientou a identificação e tornou possível a proximidade do público-alvo.

O questionário coletou dados como o sexo predominante dos participantes e sua faixa etária, considerados importantes para direcionar a elaboração do projeto aos seus reais usuários. Levantou ainda como estes participantes definiam seu conhecimento sobre o tema, os alimentos que consumiam, hábitos e práticas de preparação de suas refeições, com isso, obteve-se a real noção das características que devem ser atribuídas na elaboração do aplicativo, e por fim, ainda disponibilizou espaço a esses participantes para que sugerissem o que acreditavam ser importante em projetos do mesmo seguimento, desta forma esclarecendo mais seus anseios.

Seguindo ainda o método de Löbach (1976, p. 150): "depois que, na primeira fase do processo de design, se analisa o problema com seu entorno, na segunda fase são geradas as alternativas para o mesmo. É a fase da produção de idéias baseando-se nas análises realizadas". Sendo assim, com a análise dos dados, estabeleceu-se alguns parâmetros sobre os possíveis usuários: trata-se de um público variado, que passa por diversas fases de familiarização com o vegetarianismo, ou seja, cada público conta com uma dificuldade diferente em encontrar informações que atendam suas características, mas que lhe proporcionem também proximidade a outras categorias de alimentação dentro do vegetarianismo, como exemplo: os ovolactovegetarianos, lactovegetarianos, veganos, entre outros.

Nestes termos, como pode-se notar na Figura 1, foi elaborada uma proposta inicial de interface na qual o principal objetivo consiste em visualizar o desempenho de umas das telas 
utilizadas no aplicativo. Nesta etapa a prioridade é facilitar o acesso dos usuários as configurações, possibilitando de forma prática a seleção da dificuldade das receitas que serão indicadas a ele em sua tela inicial, os valores da produção destas receitas, como também a qual categoria de alimentação este usuário se interessa.

Figura 1 - Proposta inicial para tela de alternativas

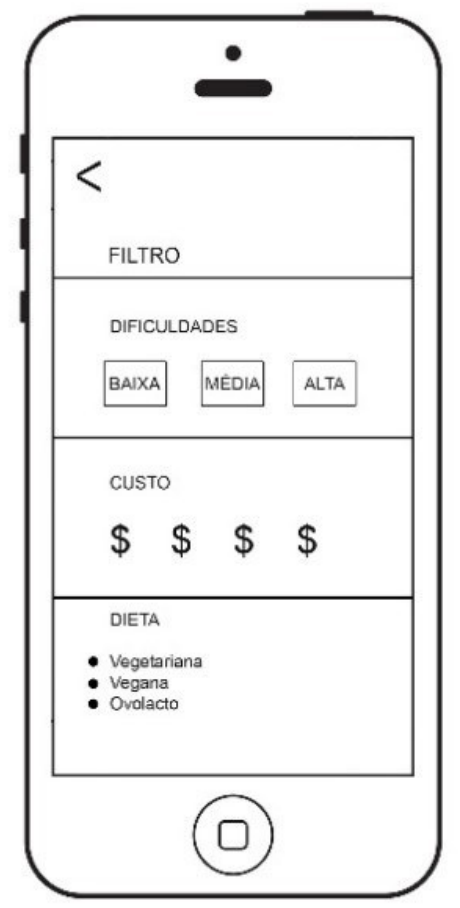

Fonte: Elaborado pelo autor

Ainda como parte da análise e geração de alternativas, destacou-se a importância de uma interface intuitiva, que permitisse aos usuários uma fácil decodificação de seus controles. A faixa etária predominante entre os respondentes, ficou entre 18 e 29 anos. Esta média de idade, segundo o IBGE (2018) representa $85 \%$ das pessoas que têm acesso a internet e que apontam os celulares como dispositivo preferido para acesso à rede, utilizando da tecnologia dos aplicativos mobile para facilitar seu cotidiano. Além disso, foi possível constatar que a maioria destes participantes definiram seu próprio conhecimento como de nível médio, abrindo-se a possibilidade de integrar na elaboração deste projeto a inserção de alternativas para a complementação do conhecimento dos usuários sobre o tema.

Conforme é apresentado na Figura 2, a proposta é que na tela inicial o usuário se depare com algumas opções de receitas sugeridas pelo próprio aplicativo a partir da configuração de suas preferências, desta forma será direcionado somente para as opções de refeições que atendam às suas especificações. Ademais, será proporcionado aos usuários o acesso fácil a uma área que possua matérias jornalísticas e artigos científicos relacionados ao vegetarianismo, assim como dicas dos próprios usuários, buscando otimizar a utilização e oferecer a possibilidade de interagir com outras pessoas que também escolheram este modo de alimentação. 
Figura 2 - Proposta realizada para tela de acesso principal
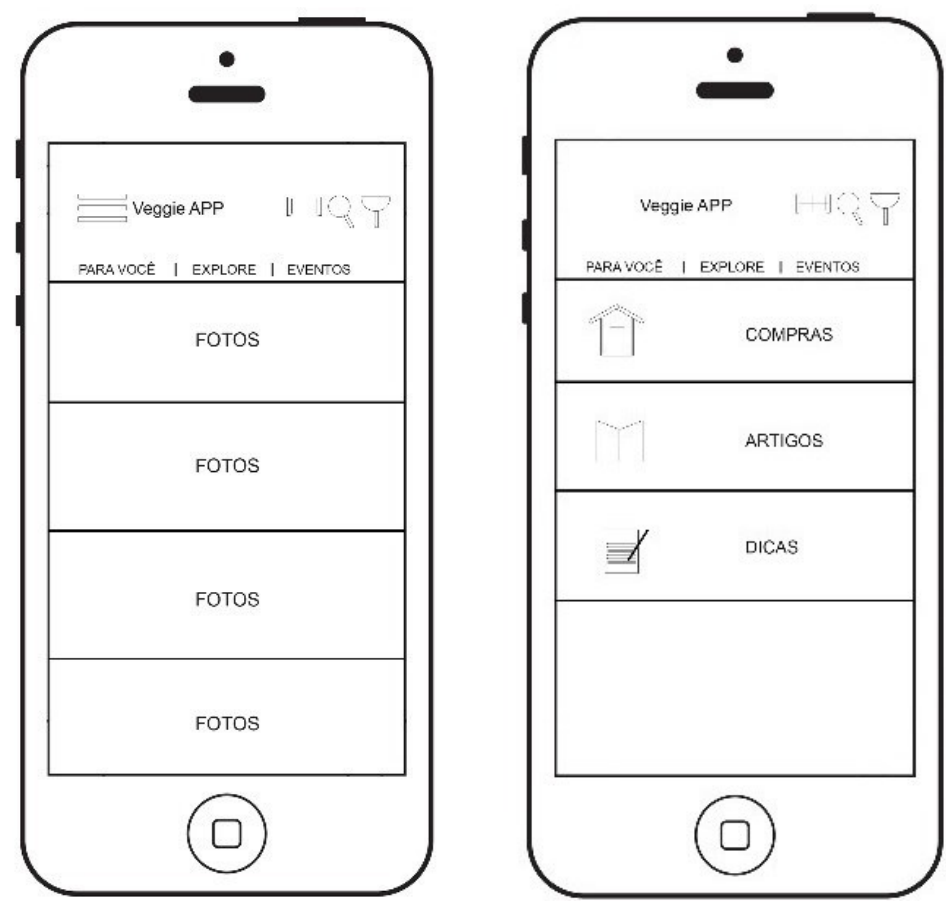

Fonte: Elaborado pelo autor

Após a junção dos dados obtidos e das características que devem ser empregadas, de acordo com Löbach (1976), é na fase de avaliação das alternativas que se pode refinar e definir aquelas que mais condizem com as propostas do projeto. Com isso, é possível descartar ideias que não correspondem à pesquisa e agora encontrar soluções consideradas mais plausíveis. A fim de tornar estas alternativas mais perceptíveis, foi preparado junto aos esboços, um painel semântico, conforme indicado na Figura 3. Este é considerado importante na elaboração do projeto, pois concretiza parte de sua estruturação, auxiliando a próxima fase definida como a de realização.

No decorrer da preparação do painel semântico foi possível estabelecer um perfil. Após reunir referências visuais que indicam as melhores alternativas a este púbico, o projeto atinge uma forma capaz de atrair visualmente aqueles que buscam informações sobre o tema, utilizando famílias tipográficas adequadas, cores e imagens, como também estratégias de usabilidade e de interface que permitem a comunicação clara e objetiva do suporte.

Como pode-se perceber na Figura 3, foi construído um painel semântico referente ao vegetarianismo, contando com algumas imagens e palavras-chave relacionadas a buscas pelo tema, desta maneira é possível visualizar características capazes de auxiliar na construção de um perfil a ser atendido. Considera-se que as informações reunidas, facilitam o reconhecimento do público-alvo, obtendo através de referências visuais pontos que são capazes de atrair a atenção destes usuários, como também descartar elementos e palavras que não condizem com o tema. 
Figura 3 - Painel semântico relativo a vegetarianismo

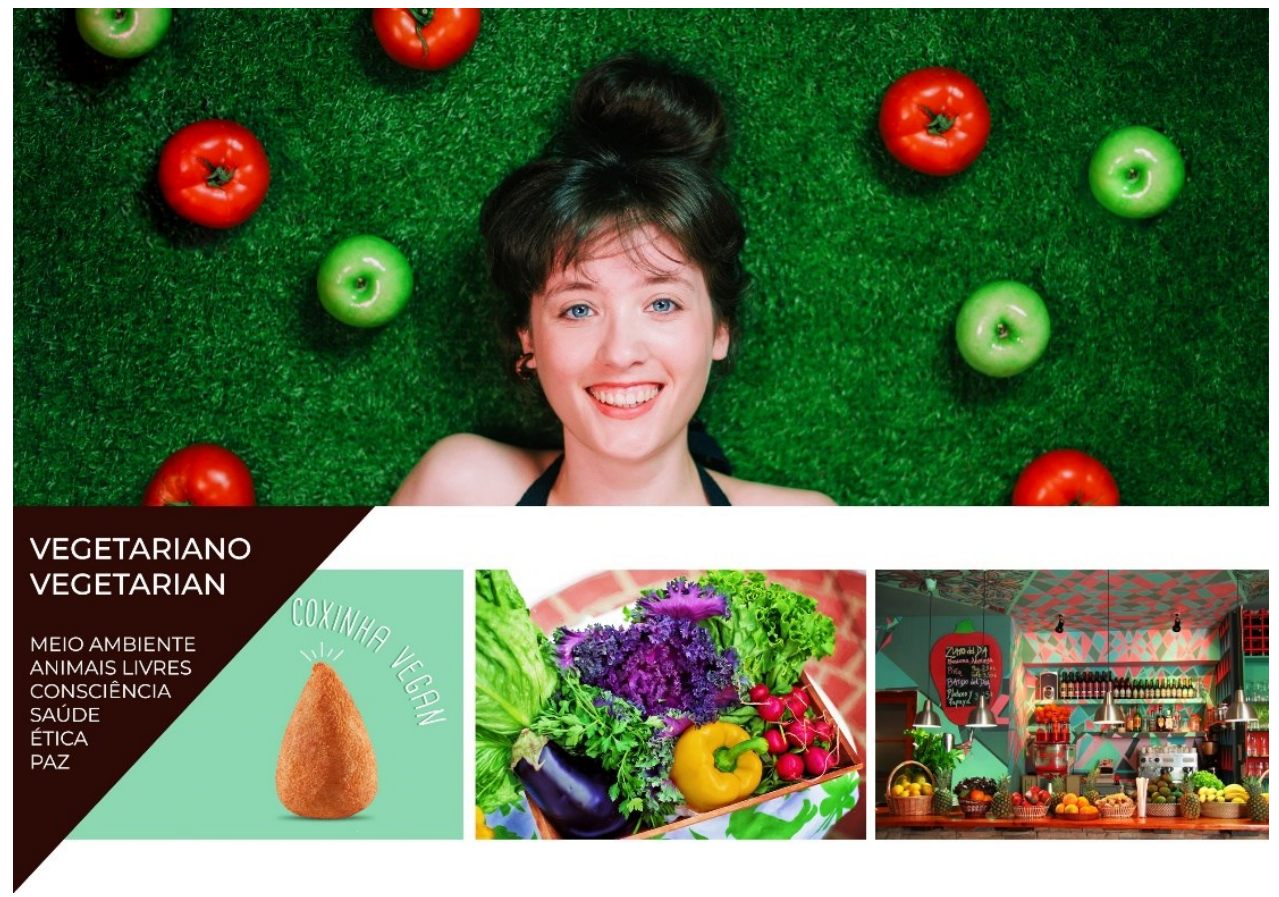

Fonte: Elaborado pelo autor

Segundo Löbach (1976), o último passo trata-se da materialização da alternativa escolhida, porém esta ainda pode ser retocada e aperfeiçoada. Entende-se que a criação de um perfil a ser seguido deve assegurar que o projeto mantenha-se na mesma temática, limitando as chances de ser aplicada linguagens diferentes que possam confundir visualmente e usualmente o usuário.

É finalmente nesta fase que o progresso é perceptível e todos os atributos finalmente serão aplicados. No decorrer da elaboração deste projeto, o logotipo foi entendido como um dos elementos responsáveis por chamar a atenção do público, é por meio da experiência visual que se inicia o interesse dos usuários, portanto é sugerido o uso de cores e elementos que se harmonizam com o tema. Conforme é apresentado na Figura 4, foi utilizado uma tipografia cursiva, que pela sua característica manual, traz ao projeto um aspecto mais familiar, porém esta será somente utilizada na tela principal, pois seu uso em outros locais e escalas compromete a legibilidade. O uso da cor verde e das folhas busca relacionar-se ao tema.

Figura 4 - Logotipo criado para uso na tela de acesso ao aplicativo

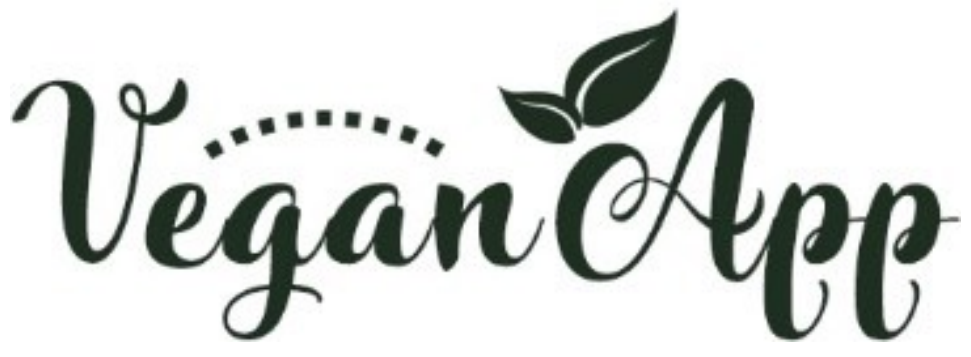

Fonte: Elaborado pelo autor 
Tendo em vista contemplar as preocupações referentes a usabilidade, optou-se pela linguagem visual Flat Design, que demonstra em suas características o minimalismo. Esta linguagem conta com ícones ilustrados e chamativos abrindo espaço para formas mais simplificadas de se representar algum objeto ou recurso, suas cores também seguem o mesmo princípio, no qual sombras e gradientes são substituídos por cores sólidas e contrastantes.

Com base nestas informações, os ícones que compõem o projeto são considerados parte essencial da interação do usuário com o suporte mobile elaborado, seu uso correto dispensa a aplicação de textos, para isso, foi definido um conjunto de ícones que conversassem entre si, que fossem intuitivos e de fácil decodificação, sendo todos utilizados sem qualquer preenchimento, assim não entrando em conflito com a linguagem Flat.

Figura 5 - Ícones selecionados para utilização no aplicativo

\section{ÍCONES UTILIZADOS}

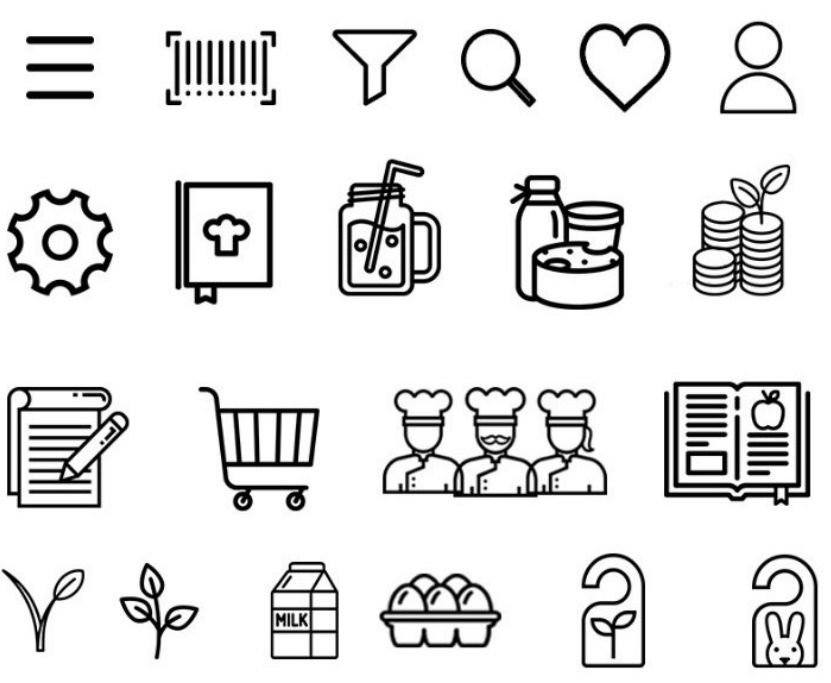

Fonte: https://www.flaticon.com/

Na sequência, foi determinada duas paletas de cores que remetessem ainda a temática atribuída ao projeto, estas são consideradas essenciais, todavia requerem muita atenção, para que sejam aplicadas de forma harmônica e que façam corretamente referência ao seu público-alvo. Como é apresentado na Figura 6, a paleta de cores utilizada possui tonalidades que foram identificadas no painel semântico, estas reúnem diferentes tons de verde e cores capazes de gerar contraste, desta forma foi possível também remeter ao estilo proposto.

A combinação destas tonalidade produzem um contraste agradável, desta forma, ao aplicar corretamente estas são capazes de propiciar uma boa leitura ao usuário, mesmo que exista a interferência dos ajustes de brilho de cada aparelho utilizado. Estas cores determinadas ao projeto, podem ser facilmente encontradas a temática do Flat Design. 
Figura 6 - Paleta de cores atribuída ao aplicativo

\section{ELEMENTOS PRINCIPAIS}

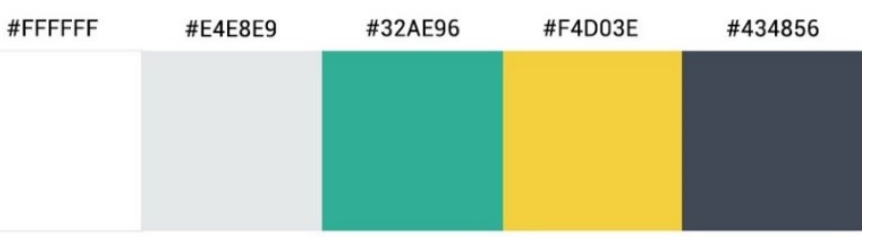

\section{ELEMENTOS DE APOIO}

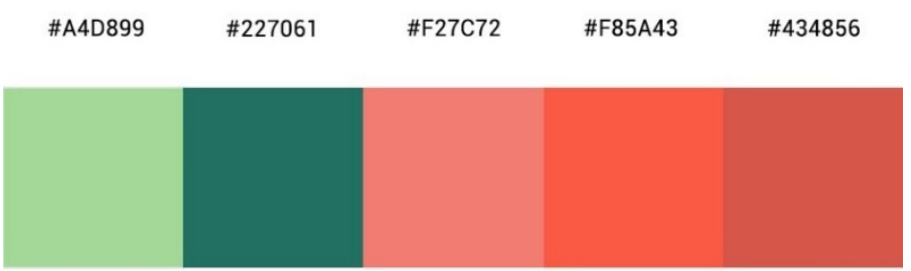

Fonte: Elaborado pelo autor

Finalmente, a tipografia deve ser considerada um dos elementos mais importante nos meios digitais ou impressos, é por meio dela que se atribui grande parte dos valores do projeto, visto que, se não for adequada impossibilita a transmissão da mensagem. Antes de atribuí-la ao projeto, foi preciso levantar questões relativas ao local onde seria aplicada, sua composição, como também seu peso e estilo, características que podem implicar no modo como as mensagens seriam transmitidas.

A tipografia escolhida para este projeto foi a Roboto, pois conforme é apresentado na Figura 7, esta possui diferentes estilos, possibilitando sua aplicação em lugares diversos. Além disso, pode ser considerada uma tipografia familiar, pois é encontrada em outros suportes mobile. A utilização de uma única tipografia em todo o projeto, garante que o mesmo seja coerente em todas as suas etapas, e que somente pelo uso variado de seus estilos, pesos e cores é possível transmitir a ideia de que os recursos disponíveis são diferentes. Sua escolha deve-se ainda a legibilidade que esta tipografia possuí, sendo este o principal requisito para suportes mobile. 
Figura 7 - Tipografia escolhida para utilização no aplicativo

TIPOGRAFIA

\section{Aa Aa Aa ROBOto \\ Bold Regular Light}

\section{ABCDEFGHIJKLMNOPQRSTUVWXYZ abcdefghijklmnopqrstuvwxyz 01234356789}

\section{ABCDEFGHIJKLMNOPQRSTUVWXYZ abcdefghijklmnopqrstuvwxyz 01234356789 \\ ABCDEFGHIJKLMNOPQRSTUVWXYZ abcdefghijklmnopqrstuvwxyz 01234356789}

Fonte: Elaborado pelo autor

\section{Resultados}

Por fim, após realizar todas as fases propostas pelo método de Löbach (1976) foi possível aplicar ao projeto as melhores soluções encontradas, estas não necessariamente se caracterizam pela primeira alternativa gerada, mas sim pela junção de boas características encontradas durante o processo.

De acordo com a Figura 8, a primeira tela à esquerda é classificada como a tela de acesso ao aplicativo, esta contém uma imagem de fundo com alimentos de origem vegetal. O objetivo do uso desta imagem é que ao primeiro contato do usuário com o aplicativo seja despertado o interesse pelo seu conteúdo. A segunda tela localizada a direita, é classificada como a tela principal, onde o usuário encontrará todos os recursos que mais necessita, desta maneira, considera-se que a usabilidade é alcançada. 
Figura 8 - Tela de acesso e tela inicial do aplicativo
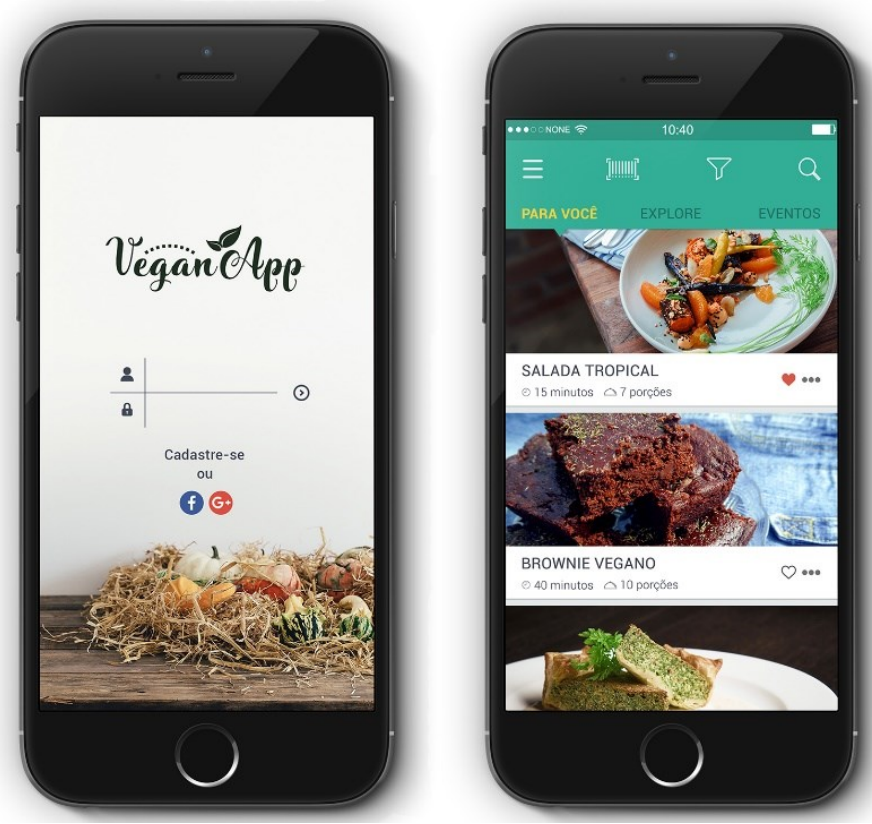

Fonte: Elaborado pelo autor

A seguir é apresentado na Figura 9, as telas referentes ao acesso do menu, localizado na lateral superior esquerda do aplicativo. Acessando este local o usuário terá a possibilidade de alterar sua conta, preferências e uma seção de favoritos, assim como é apresentado na tela do lado esquerdo. A cor de tonalidade rosa caracteriza a seleção executada, ao ser selecionada a barra irá para o topo da tela, conforme é exibido ainda na tela central.

Ainda na opção de favoritos, ao usuário efetuar novamente a seleção a cor será alterada, porém agora para uma azul, conforme apresentado na tela central. A troca de cores, visa guiar o usuário na navegação, e mesmo possuindo cores distintas, todos os recursos serão acompanhados do texto de suas funções, extinguindo qualquer possibilidade de dificuldade na navegação. 
Figura 9 - Telas referentes ao acesso do menu
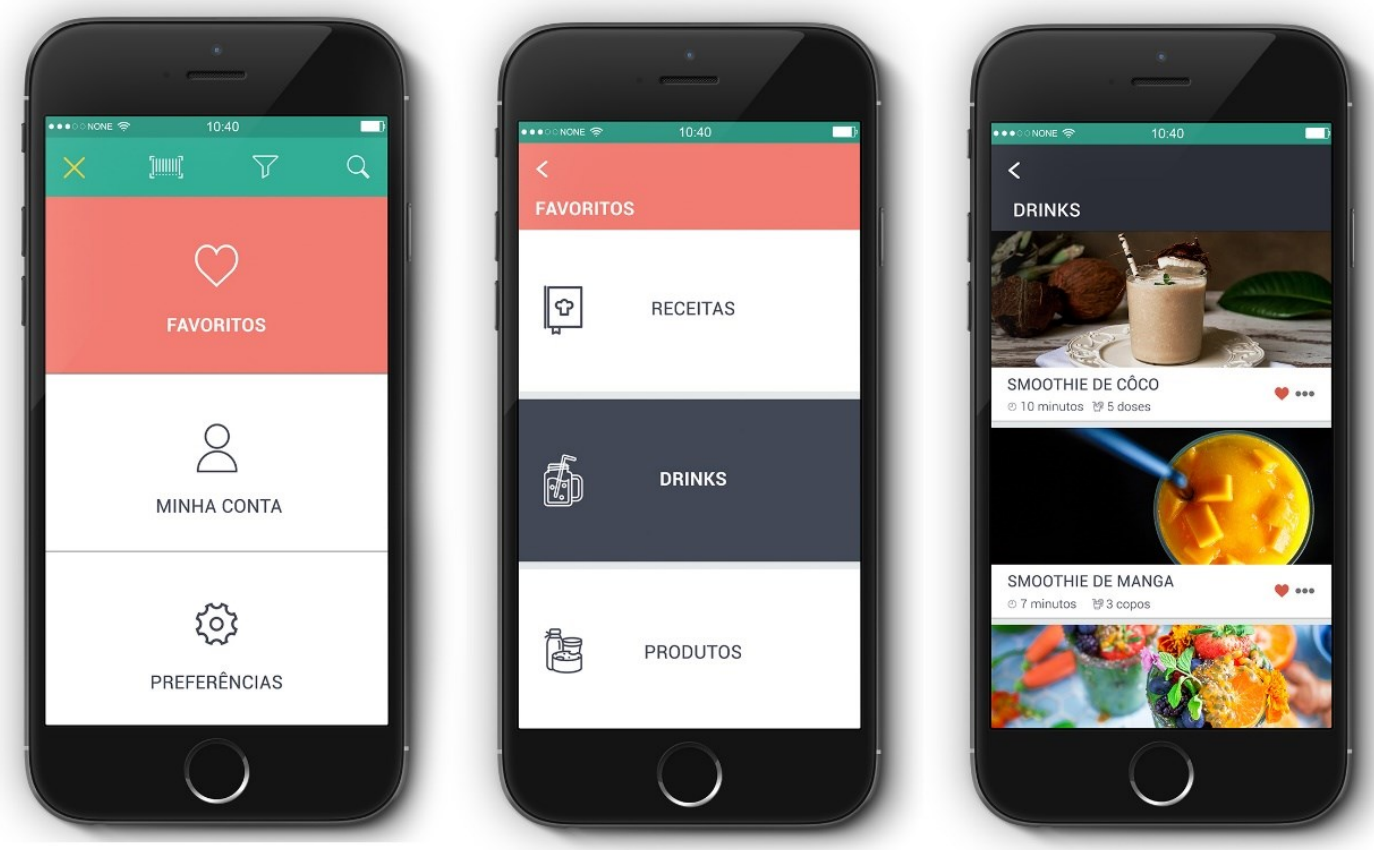

Fonte: Elaborado pelo autor

Na figura 10, é apresentada a função do segundo ícone localizado ao lado direito do menu na tela principal. Acessando este ícone será possível que o usuário efetue pesquisas sobre as propriedades do produto através do seu código de barras. A tela localizada ao centro e a direita, apresenta a maneira como este usuário receberá as informações que deseja.

\section{Figura 10 - Tela de pesquisa por código de barras}
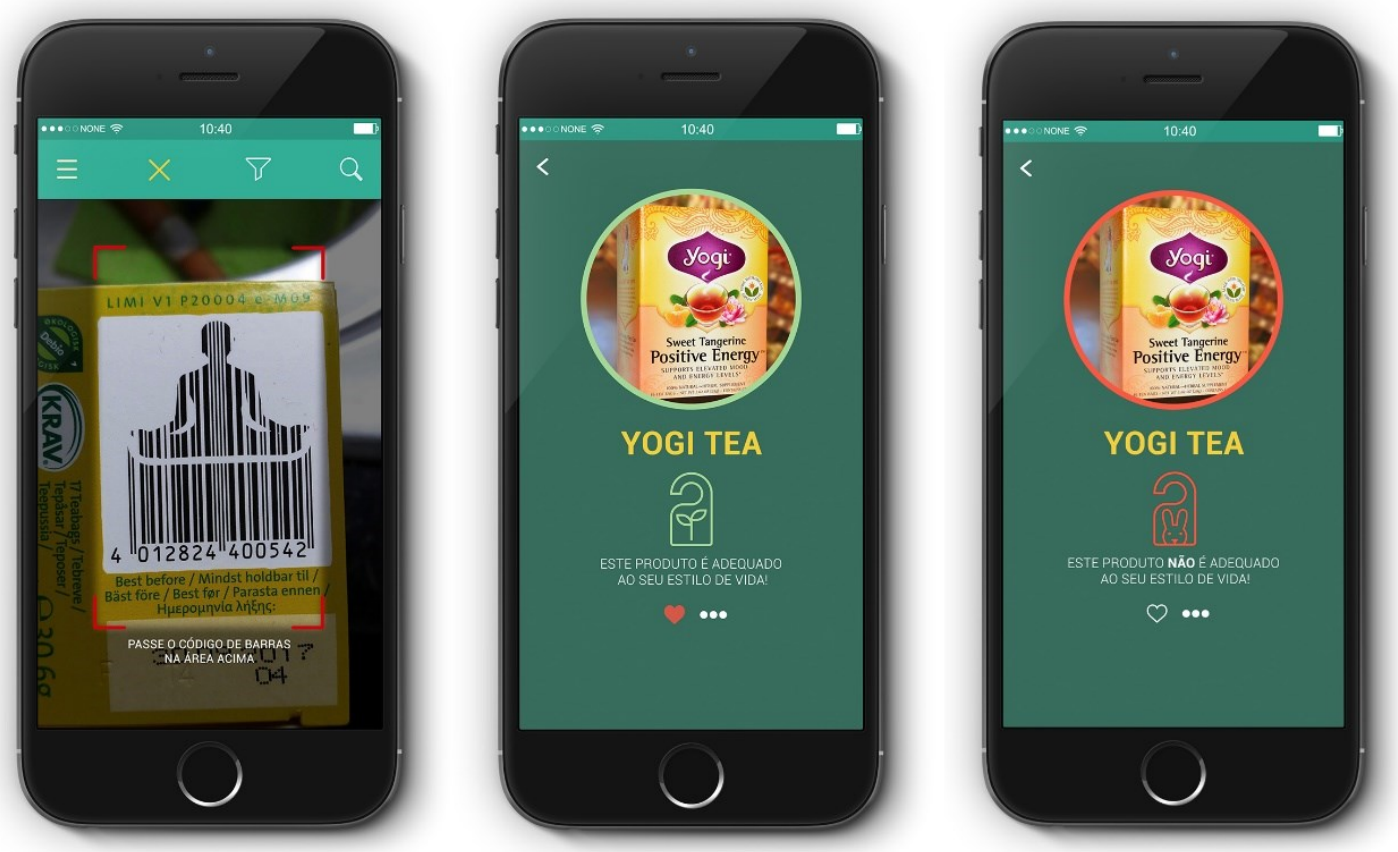

Fonte: Elaborado pelo autor 
Segundo a Figura 11 é apresentado na tela ao lado esquerdo o terceiro ícone após o menu que se trata da opção de filtros, onde através dele será possível selecionar as características de alimentação conforme as necessidades do usuário, desta forma sua tela principal apresentará sugestões condizentes com os ícones selecionados no filtro. Na tela localizada ao centro, observase uma segunda barra, está representada por palavras. Ao acessar a opção nomeada como "Explore", será disponibilizado uma seção referente a artigos científicos, matérias jornalísticas e textos do tema, como também uma seção destinada a dicas e locais de compras. Na tela à direita, observa-se a disposição dos artigos disponíveis.

Figura 11 - Tela de acesso ao filtro e artigos
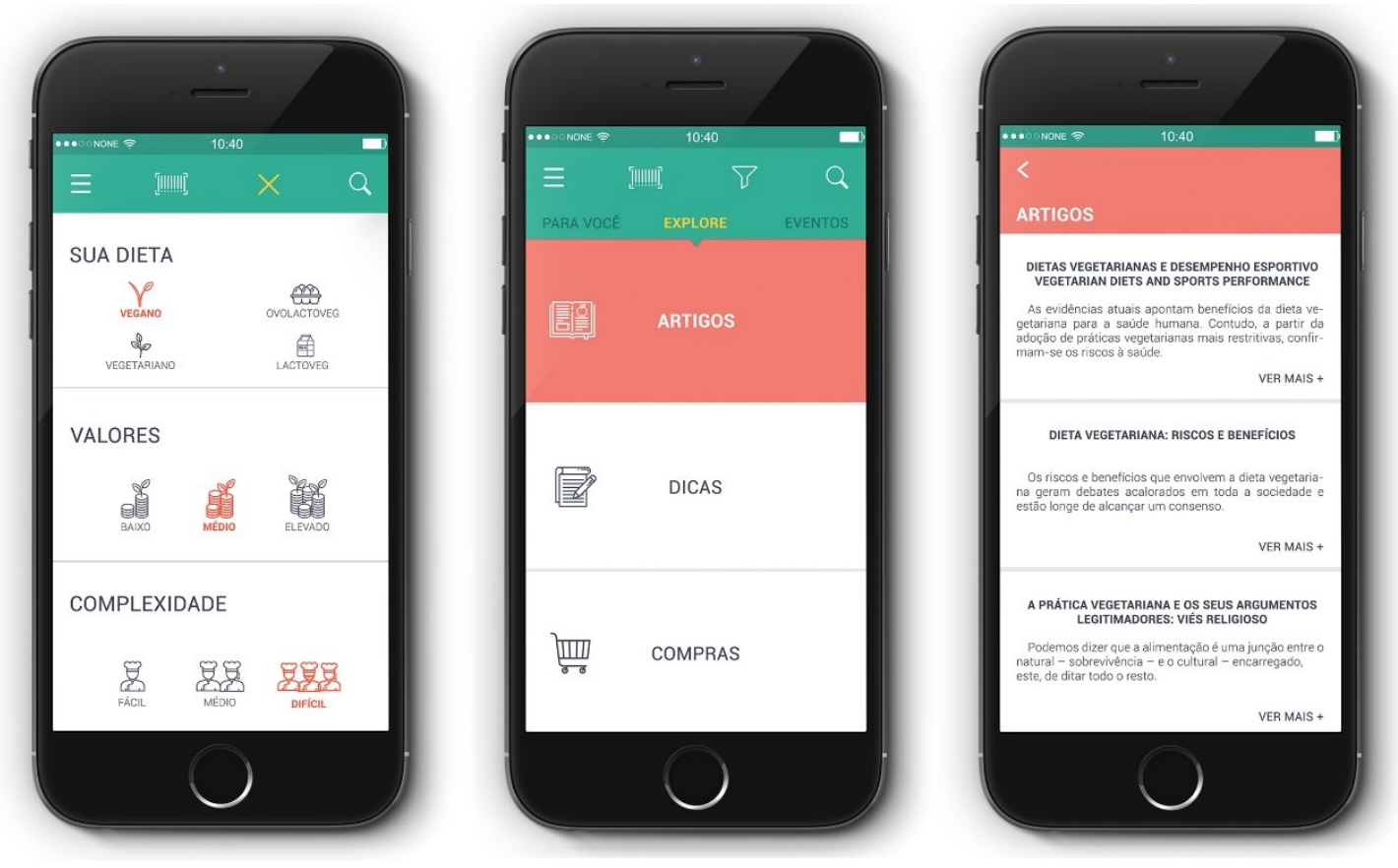

Fonte: Elaborado pelo autor 


\section{Considerações finais}

A proposta e elaboração deste projeto, consiste em garantir que o público vegetariano, como também seus novos adeptos, possam adquirir informações e sanar qualquer tipo de anseio ou dúvida que possuam em relação ao vegetarianismo. A escolha por um suporte mobile para aplicação deste propósito, deve-se à crescente expansão tecnológica que busca auxiliar a vida humana, oferecendo às pessoas oportunidades de informarem-se de forma prática e adaptada ao cotidiano.

Este projeto torna-se marcante, pois realça a importância da organização, dos estudos e da aplicação de métodos que possam auxiliar o processo de criação e execução de qualquer projeto, permitindo ainda, a aplicação de um tema em constante crescimento, mas que ainda possui pouca visibilidade. Desta maneira, é possível reunir temas distintos com características atuais.

Destaca-se que o desafio atribuído a este projeto é reunir de forma adequada elementos distintos, fazendo que estes possam ocupar o mesmo espaço e fazerem sentido, sem que interfiram ou sejam desarmoniosos. Assim, a busca incessante por conhecimento e a criação de alternativas que sintetizem todas as dificuldades do público-alvo, possibilitam que o design tornese a cada dia um dos maiores aliados na melhora da condição de vida humana. 


\section{Referências}

BONSIEPE, G. Design, cultura e sociedade. São Paulo: Blucher, 2011.

LÖBACH, B. Design Industrial: Base para a configuração dos produtos industriais. Rio de Janeiro: Editora Edgard Blücher, 1976.

MUNARI, B. Das coisas nascem coisas. São Paulo: Martins Fontes. 1981.

PETTERSSON, R. It Depends: ID - Principles and guidelines. Tullinge, Sweden, 2002.

RODRIGUES, C. Introdução ao vegetarianismo. 2 ed. São Paulo: Galaxia Alfa, 2005.

SANTAELLA, L. O que é Semiótica. Coleção primeiros passos. São Paulo: Brasiliense, 1983.

DEMARTINI, F. Brasil tem 116 milhões de usuários de internet, afirma IBGE. In: Canaltech, 2018. (https://canaltech.com.br) 